\title{
Telescopic straight ileo-anal anastomosis in $\operatorname{dogs}^{1}$
}

\author{
Anastomose íleo-anal direta por telescopagem em cães
}

\author{
Renato Arioni Lupinacci', Renato Micelli LupinacciII, Martin Zavadinack Netto ${ }^{\text {III }}$
}

${ }^{\mathrm{I}} \mathrm{PhD}$, Head, Department of Surgery, Public Employees Hospital, Sao Paulo, Brazil. Main author. Responsible for conception, design, intellectual and scientific content of the study.

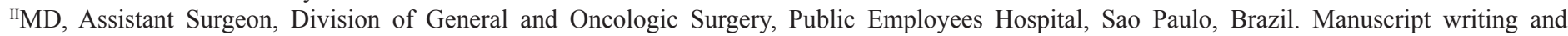
interpretation of data.

${ }^{\text {III }} \mathrm{PhD}$, Department of Surgery, State University of Maringa, Parana, Brazil. Involved with technical procedures and manuscript writing.

\begin{abstract}
PURPOSE: To study outcomes and functional results of a telescopic straight ileo-anal anastomosis.

METHODS: Thirty-six mongrel dogs were submitted to total proctocolectomy and telescopic straight ileo-anal anastomosis (ileal mucosa-submucosa pulled-through the rectal cuff). They were divided in 3 groups, sacrificed after one, two or eight weeks after the initial procedure. Gross and microscopic (degree of cooptation and signs of ischemia) aspects of the anastomosis, as well, the aspect of defecation were analyzed. RESULTS: On microscopy all anastomosis analysed showed a continuous epithelial line and were considered good. After two-months no signs of ischemia were identified. Defecation aspect has considerably changed during the study, so no dogs presented solid defecation within the first two weeks, whereas $80 \%$ of dogs presented solid stools after two months.

CONCLUSION: Telescopic ileo-anal anastomosis is a safe alternative and may provide good functional results after some small period of time.

Keywords: Colectomy. Anastomosis, Surgical. Colorectal Surgery. Dogs.

\section{RESUMO}

OBJETIVO: Estudar os resultados cirúrgicos e funcionais de uma anastomose íleo-anal por telescopagem.

MÉTODOS: Trinta e seis cães sem raça definida foram submetidos à procto-colectomia total e anastomose ileo-anal por telescopagem da mucosa-submucosa ao coto retal. Os animais foram divididos em três grupos cujos sacrifícios ocorreram 1, 2 e 8 semanas após o procedimento inicial. $\mathrm{O}$ aspecto da anastomose foi analisado no momento do sacrifício e microscopicamente (grau de coaptação e sinais de isquemia), bem como o aspecto da evacuação nos canis de cada cão.

RESULTADOS: O estudo microscópico evidenciou continuidade do epitélio em todas as anastomoses. Nos cães sacrificados após dois meses não houve sinais de isquemia nas anastomoses. $\mathrm{O}$ aspecto das fezes alterou-se consideravelmente com o tempo, assim, enquanto nenhum cão apresentou fezes sólidas nas primeiras duas semanas, ao término do segundo mês $80 \%$ dos cães apresentavam fezes sólidas na maior parte do tempo.
\end{abstract}

CONCLUSÃO: A anastomose íleo-anal por telescopagem é uma alternativa segura e pode assegurar bons resultados funcionais após alguns meses.

Descritores: Colectomia. Anastomose Cirúrgica. Cirurgia Colorretal. Cães. 


\section{Introduction}

Ileal pouch anal anastomosis (IPAA) has become the standard of care for reconstruction after total proctocolectomy for ulcerative colitis (UC) or familial polyposis. One of the main interests of ileo-anal anastomosis is to allow patients to have a satisfactory continence of stool while avoiding the disagreeable inconvenience of ileostomy, however, the anatomical modification result nonetheless in a significant alteration in the frequency of stool evacuation with several daytime and almost always some nocturnal bowel movements.

Moreover, IPAA is associated with early and late complications. Anastomosis dehiscence, abscess and pelvic septicemia, and fistulae are not uncommon and total rate of early complications may reach $43.7 \%^{1,2}$. Long-term complications, notably pouchitis, irritable pouch syndrome, and anastomotic stricture may be present in more than $60 \%, 46 \%$ and $38 \%$ respectively ${ }^{3-6}$.

Failure is defined as the need to excise the reservoir or the need for a permanent ileostomy. The rate ranges from 3.5 to $15 \%$, and the main causes are: unrecognized Crohn's disease, persistent pelvis sepsis, mediocre functional results, desmoids tumors, and tumor recurrence ${ }^{7,8}$. To reduce this failure rate, several teams have developed techniques to salvage the reservoir.

We thought that a telescopic straight ileo-anal anastomosis could be an usefull technique in re-do ileo-anal anastomoses when the reservoir must be taken off. The preservation of the rectal muscular cuff with its nerve-endings, associated with a telescopic mucosa/submucosa ileo-anal anastomosis, may provide a safe anastomosis with acceptable functional results. Therefore experimental studies are of value tojudge the results of the technique by an objective assessment.

\section{Methods}

The study protocol was analyzed and approved by the Research Ethics and Animal Care and Use Committees of the Federal University of Sao Paulo (UNIFESP). The use of laboratory animals followed the ethical code for animal experimentation of the Council for International Organization of Medical Sciences and the Brazilian College on Animal Experimentation.

Thirty-six mongrel dogs (16 males) weighting $8-20 \mathrm{Kg}$ (median: $11.8 \mathrm{Kg}$ ) were used. They remained 14 days before surgery at the hospital kennel to receive nutritional support and phytosanitary treatment. Procedures were performed at the Laboratory for Experimental Surgery, Public Employees Hospital under anesthesia of sodium pentobarbital. Dogs had no bowel preparation or perioperative intravenous antibiotic. Rectal stump irrigation was systematically performed with PVPI solution just before rectal section. A bland diet was given after the fifth postoperative day, during the first two post-operative days dogs were left with water ad libitum and then allowed to drink milk.

\section{Operative technique}

Dogs were positioned in a supine position. Standard skin preparation and sterile draping was then performed. Abdominal time: The procedure consisted of a total colectomy, with the rectum transected at the level of the levators leaving a rectal cuff of approximately $3 \mathrm{~cm}$. The left mesenteric artery was ligated at its origin, but at the right side, only secondary branchs of the ileocolic artery were sectioned, preserving the ileo-colic arcade. Ten centimeters of the distal ileum was resected with the colon (Figure 1). Then a circumferential resection of the seromuscular layer of the ileum with $4 \mathrm{~cm}$ long was performed (Figure 2). Perineal time: Rectal mucosectomy was performed transanally beginning at the dentate line. Telescopic ileo-anal anastomoses was performed with interrupted 3-0 Vicryl sutures placed close together incorporating anoderm, internal sphincter, and the mucosa-submucosa of the pulled-through ileum (Figure 3).

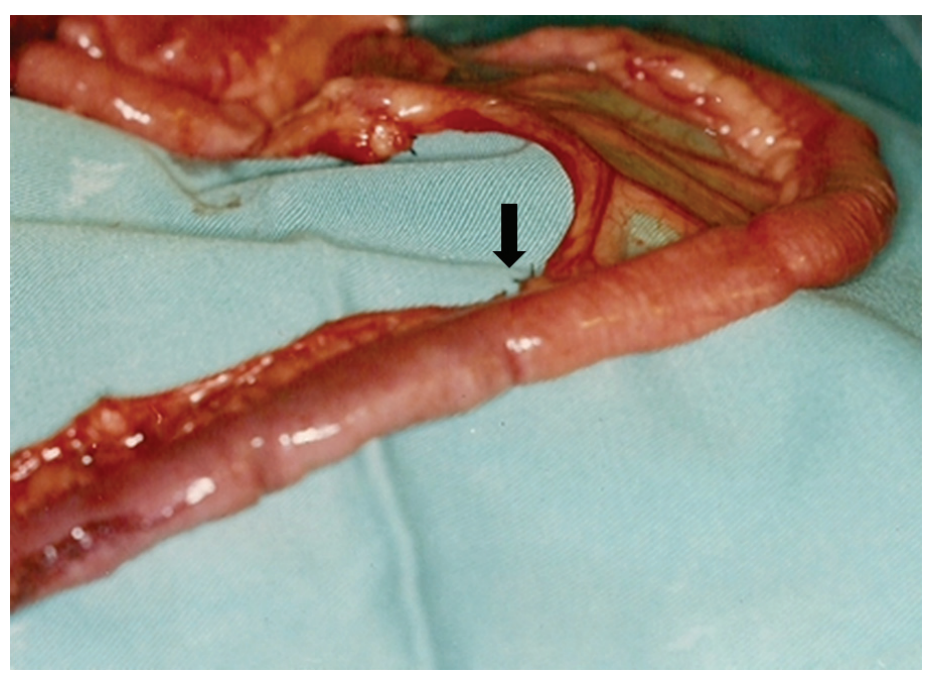

FIGURE 1 - Preparation of the terminal ileum. Section of ileal arcade (arrow). 


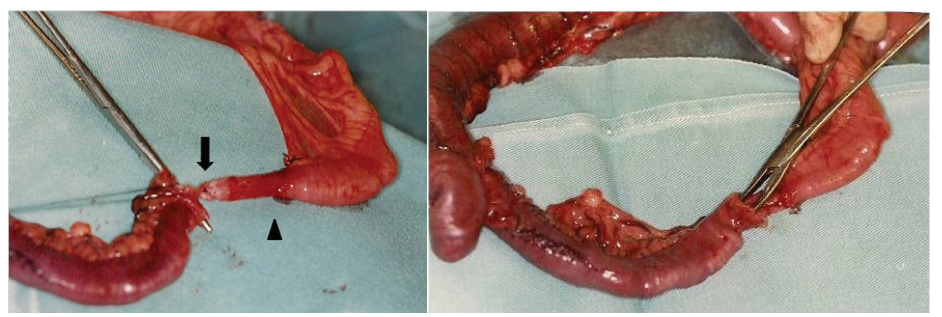

FIGURE 2 - Preparation of terminal ileum. A. Resection of sero-muscular layer. B. Submucosa-mucosa $4 \mathrm{~cm}$ long graft. Distal end (arrow). Proximal end (arrow head).

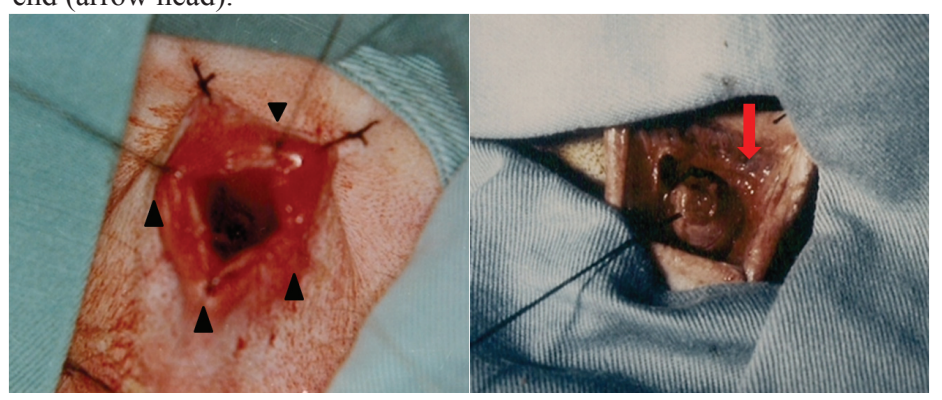

FIGURE 3 - Telescopic ileo-anal anastomosis. A. The submucosamucosa graft (star) is pulled-through the muscular rectal cuff (arrow). B. 4 cardinal (arrow heads) interrupted sutures incorporating anoderm, internal sphincter, and the mucosa-submucosa of the pulled-through ileum.

The animals were then divided in 3 groups of ten animals. Each group corresponded to a specified period of postoperative observation (Group 1, 1 week; Group 2, 2 weeks; and Group 3, 2 months). The post-operative observation consisted of: clinical evaluation and anatomo-pathological study of the anastomotic zone.

The pelves of sacrificed dogs were dissected for gross observation and fixed en block in formalin for microscopic examination. Gross aspect of the anastomoses and diameter of anal orifice or ileo-anal anastomoses were evaluated minutes before procedure and/or sacrifice when the dogs were already positioned.

Transverse serial sections of 4 longitudinal strips (one of each cardinal point) of the pulled-through ileo-anal anstomosis and the rectal cuff were studied. They were stained with hematoxylin and eosin, and analyzed by a GI pathologist who was blind to which group the specimen was taken. The microscopy examined the degree of coaptation and ischemia.

We tried to analyse the gross aspect of dog's defecation by cleaning their kennel 3-times a day, and classifying it as liquid or solid. The aspect of the majority of defecation episodes was considered for analysis.

\section{Statistical analysis}

Comparison of groups were performed by KruskalWallis test. Functional and technical results were analyzed using Chi-square test to test for significant differences.

\section{Results}

\section{Surgical morbidity and mortality}

Six dogs died before one week (mortality rate: 16.6\%) and were not considered for analysis. Wound infection rate was $13.3 \%$ and $3 / 30(10 \%)$ animals developed small $(3,5$ and $6 \mathrm{ml})$ pelvic abscess discovered during pelvic dissection after sacrifice (Table 1).

TABLE 1 - Pelvic abscess.

\begin{tabular}{ccc}
\hline Groups & Pelvic abscess & \% pelvic abscess \\
\hline I & $2 / 10$ & $20 \%$ \\
II & $1 / 10$ & $10 \%$ \\
III & $0 / 10$ & $0 \%$ \\
Total & $3 / 30$ & $10 \%$ \\
\hline
\end{tabular}

${ }^{*}$ Chi-square test: NS: Non significant differences in pelvic abscess occurrence between groups

\section{Cooptation}

Gross aspects of cooptation were considered good in 7/10, 8/10 and 10/10 in groups I, II and III respectively. On microscopy, one-hundred percent of anastomosis, independently of the post-operative time, showed a continuous epithelial line and were considered good (Table 2).

TABLE 2 - Morphological aspects of anastomosis.

\begin{tabular}{ccccc}
\hline & I & II & III & \\
\hline $\begin{array}{c}\text { Cooptation - } \\
\text { Gross aspect } \\
\text { (not cooped) }\end{array}$ & $3 / 10$ & $2 / 10$ & $0 / 10$ & \\
\hline $\begin{array}{c}\text { Cooptation - } \\
\text { Microscopic } \\
\text { aspect } \\
\text { (not cooped) }\end{array}$ & $0 / 10$ & $0 / 10$ & $0 / 10$ & \\
$\begin{array}{c}\text { Signs of } \\
\text { Ischemia } \\
\text { (present) }\end{array}$ & $4 / 9(44.4 \%)$ & $2 / 8(25 \%)$ & $0 / 9(0 \%)$ & $N S^{*}$ \\
\hline
\end{tabular}

*NS: Non significant difference between groups 


\section{Ischemia}

Signs of ischemia were identified by microscopy in 4/10, and 2/10 dogs of groups 1 and 2 respectively. Anastomosis from group 3 did not show any clear signs of ischemia (Table 2).

\section{Diameter of anastomosis}

Anal sphincter and ileo-anal anastomose diameter were measured for dogs from group 3. In six animals there were a decrease in the diameter (ranging from $9.5 \%$ to $17.4 \%$ ) (Table 3 ).

TABLE 3 - Comparison of diameters (only for group III).

\begin{tabular}{cccc}
\hline Dog & $\begin{array}{c}\text { Anal sphincter } \\
(\mathbf{m m})\end{array}$ & $\begin{array}{c}\text { TIAA } \\
(\mathbf{m m})\end{array}$ & $\begin{array}{c}\text { Difference } \\
\mathbf{( \% )}\end{array}$ \\
\hline $\mathbf{2 1}$ & 22 & 19 & 13.6 \\
$\mathbf{2 2}$ & 21 & 19 & 9.5 \\
$\mathbf{2 3}$ & 23 & 19 & 17.4 \\
$\mathbf{2 4}$ & 23 & 20 & 13 \\
$\mathbf{2 5}$ & 20 & 20 & 0 \\
$\mathbf{2 6}$ & 22 & 22 & 0 \\
$\mathbf{2 7}$ & 19 & 17 & 10.5 \\
$\mathbf{2 8}$ & 18 & 16 & 11.1 \\
$\mathbf{2 9}$ & 19 & 19 & 0 \\
$\mathbf{3 0}$ & 19 & 19 & 0 \\
\hline
\end{tabular}

Chi-square test: $\mathrm{p}<0.05$

\section{Functional results}

No animals in group I and II had solid episodes of defecation. Eight of ten $(80 \%)$ animals in group III showed a majority of solid episodes (Table 4).

TABLE 4 - Aspect of stools.

\begin{tabular}{ccc}
\hline Group & Solid & Liquid \\
\hline I & 0 & 10 \\
II & 0 & 10 \\
III & 8 & 2 \\
\hline
\end{tabular}

\section{Discussion}

Ileal pouch anal anastomosis has gained worldwide acceptance as the procedure of choice after restorative proctocolectomy, and is associated with a significantly better perception of body image than a permanent stoma. However, some authors argue that quality of life in general is similar in both groups, and patients with a pouch had more long-term complications than patients with an ileostomy within the same period of time ${ }^{9}$.

Stoller et $a l .{ }^{10}$ showed that the terminal ileum may improve its capacity of absorption within time and may work as a more physiologic reservoir without its associated complications. Despite the fact that we could not measure the number of bowel movements, and considering that fecal aspect is linked to functional results as more solid defecation are easy to be controlled, we have clearly demonstrated that although no dogs had solid defecation after 1 or 2 weeks, $80 \%$ of dogs had solid defecations after 2 months, what can be easily attributed to the capacity of adaptation of the terminal ileum.

Also, physiologic studies have demonstrated that sensory nerve-endings are found at the perineal skin until the anal transitional line, but rarely underneath the rectal mucosa ${ }^{11}$. Moreover, Parks and Nicholls ${ }^{12}$ initially showed that acceptable continence could be provided with preservation of the internal anal sphincter, sufficient rectal muscle wall and its intrinsic nervous plexus connected to sacral segments of spinal cord.

Most of short and long-term complications of the IPAA are related to the pouch itself. Pouch construction demands a long stapled line which increases the risk of fistulae, pelvic abscess, and within time anal stenosis. Also, the bacterial overgrowth promoted by the pouch environment, especially in patients with inflammatory bowel diseases, is considered the most reasonable explanation to pouchitis and irritable pouch syndrome, very common features of this technique, and not always so easy to deal.

With the above mentioned statements we thought that for selected patients this technique could avoid the complications linked to the reservoir and achieve better functional outcomes, with good results within some months after surgery.

Another theoretical use of this technique is for salvage procedures. Septic complications related to the ileal pouch-anal anastomosis after restorative proctocolectomy have been reported in up to 16 percent of patients in major series. Although a commom problem, management strategies are not well established and multiple procedures may often be necessary to achieve complete healing. After salvage procedures pouch function is usually retained in no more than $60 \%$ of patients ${ }^{13}$. Salvage procedures 
may be done via abdominal or perineal approachs, the later been preferred because of less morbidity and better outcomes in most series $^{13,14}$. Dehni et al. ${ }^{14}$ have proposed two different surgical approaches. The trans-anal approach is used preferentially for lowlying fistulae and for anastomotic strictures as long as the reservoir is of satisfactory size and the stricture is not fixed and fibrotic. The abdominoperineal approach is used when the above- mentioned conditions are not met. However, whenever reconstruction of the anastomosis is chosen, the complication rate is higher than for the initial intervention.

Telescopic anastomosis are thought to be safe and provide good results in difficult surgical situations ${ }^{15}$. In our study, all anastomosis showed a continuous epithelial line, which confirmed that a $4 \mathrm{~cm}$ mucosa-submucosa graft may be adequately perfused by the submucosal vascular net, embebetion, and even mucosal regeneration, providing a safe option in this hazardous situations. The theoretical possibility that this technique improves the functional results of ileo-anal anastomosis deserves other studies before come to practice.

\section{Conclusion}

Telescopic straight ileo-anal anastomosis show excellent early results with complete mucosa to mucosa cooptation and low rate of pelvic abscess.

\section{References}

1. Benavente-Chenhalls L, Mathis KL, Dozois EJ, Cima RR, Pemberton JH, Larson DW. Laparoscopic ileal pouch-anal anastomosis in patients with chronic ulcerative colitis and primary sclerosing cholangitis: a case-matched study. Dis Colon Rectum. 2008;51(5):549-53.

2. Canedo JA, Pinto RA, McLemore EC, Rosen L, Wexner SD. Restorative proctectomy with ileal pouch-anal anastomosis in obese patients. Dis Colon Rectum. 2010;53(7):1030-4.

3. Lovegrove E, Tilney HS, Heriot AG, von Roon AC, Athanasiou T, Church J, Fazio VW, Tekkis PP. A comparison of adverse events and functional outcomes after restorative proctocolectomy for familial adenomatous polyposis and ulcerative colitis. Dis Colon Rectum. 2006;49:1293-306.

4. Prudhomme M, Dozois RR, Godlewski G, Mathison S, FabbroPeray P. Anal canal strictures after ileal pouch-anal anastomosis. Dis Colon Rectum. 2003;46:20-3.

5. Marcello PW, Roberts PL, Schoëtz DJ Jr, Coller JA, Murray JJ, Veidenheimer MC. Long-term results of the ileo-anal pouch procedure. Arch Surg. 1993;128:500-3

6. Krausz MM, Duek SD. Restorative proctocolectomy with ileal pouch-anal anastomosis for ulcerative colitis and familial adenomatous polyposis: twenty years follow-up in 174 patients. Isr Med Assoc J. 2005;7(1):23-7.

7. Fazio VW, ZIV Y, Church JM, Oakley JR, Lavery IC, Milsom JW, Schroeder TK. Ileal pouch-anal anastomoses complications and function in 1005 patients. Ann Surg. 1995; 222(2):120-7.

8. Tulchinsky H, Hawley PR, Nicholls J. Long-term failure after restorative proctocolectomy for ulcerative colitis. Ann Surg. 2003;238(2):229-34.

9. Camilleri-Brennan J, Munro A, Steele RJ. Does an ileoanal pouch offer a better quality of life than a permanent ileostomy for patients with ulcerative colitis? J Gastrointest Surg. 2003;7(6):814-9.

10. Stoller DK, Coran AG, Drongowski RA, Bank ER. Physiologic assessment of the four commonly performed endorectal pullthroughs. Ann Surg. 1987;206:586-94.

11. Duthie HL, Gairns FW. Sensory nerve-endings and sensation in the anal region of man. Br J Surg. 1960;47:585-95.

12. Parks AG, Nicholls RJ. Proctocolectomy without ileostomy for ulcerative colitis. Br J Med. 1978;2:85-8.

13. Gorfine SR, Fichera A, Harris MT, Bauer JJ. Long-term results of salvage surgery for septic complications after restorative proctocolectomy: does fecal diversion improve outcome? Dis Colon Rectum. 2003;46(10):1339-44.

14. Dehni N, Remacle G, Dozois RR, Banchini F, Tiret E, Parc R. Salvage reoperation for complications after ileal pouch-anal anastomosis. Br J Surg. 2005;92(6):748-53.

15. Kim SH, Lee KW, Kim YK, Cho SY, Han SS, Park SJ. Tailored telescopic reconstruction of the bile duct in living donor liver transplantation. Liver Transpl. 2010;16(9):1069-74.

\section{Correspondence:}

Renato Arioni Lupinacci

Av. dos Chibarás, 688/81

04076-003 São Paulo - SP Brasil

Tel: (55 11)5054-2720

rlupinacci@uol.com.br

Received: January 13, 2011

Review: March 17, 2011

Accepted: April 18, 2011

Conflict of interest: none

Financial source: none

${ }^{1}$ Research performed at Experimental Surgical Center, Public Employees Hospital, Postgraduate Program, Department of Surgery, Faculty of Medicine, Federal University of Sao Paulo (UNIFESP), Brazil. 